Walisongo Law Review (Walrev), Vol 2 No. 2 (2020)

DOI: 10.21580/Walrev/2020.2.2.6597

Copyright (C) 2020 Walisongo Law Review (Walrev)

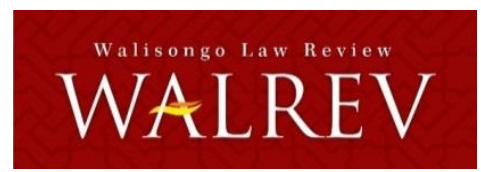

\title{
The Role of Judges in Dealing with Community Development
}

\author{
Maulana Hasanudin
}

Afiliasi: Universitas Galuh, Ciamis

Email: maulhasan.indonesia@gmail.com

\begin{abstract}
The purpose of this paper is to determine the role of the judge in facing the development of society. Judges are part of the important structure of the judicial power branch in Indonesia. Judicial power is an independent power to administer justice in order to uphold law and justice. Judges are given the power to judge. Judges have an important role as law enforcement officers in the law enforcement process in Indonesia, so they must pay attention to legal objectives. The role of the judge has consequences for the responsibility of the judge which is very heavy, where the judge has responsibility to one God, to the nation and state, to himself, to the law, to the parties and to society. Judges and society are elements that cannot be separated in a legal system. The judge is a product of the society and culture where he comes from and is. The function of the judiciary is to decide disputes between individuals and individuals, individuals and communities, even individuals or society and the state; forming or making a policy or policy.
\end{abstract}

[]

Tujuan penulisan ini adalah mengetahui peranan peranan hakim dalam menghadapi perkembangan masyarakat. Hakim merupakan bagian dari struktur penting cabang kekuasaan kehakiman di Indonesia. Kekuasaan Kehakiman merupakan 
kekuasaan yang merdeka untuk menyelenggarakan peradilan guna menegakkan hukum dan keadilan. Hakim diberi wewenang untuk mengadili. Hakim memiliki peranan penting sebagai aparat penegak hukum dalam proses penegakan hukum di Indonesia, sehingga harus memperhatikan tujuan hukum. Peranan hakim memiliki konsekuensi terhadap pertanggungjawaban hakim yang sangat berat, dimana hakim memiliki tanggung jawab terhadap tuhan yang maha esa, terhadap bangsa dan negara, terhadap diri sendiri, terhadap hukum, terhadap para pihak dan terhadap mayarakat. Hakim dan masyarakat merupakan unsur yang tidak bisa dilepaskan dalam suatu sistem hukum. Hakim sebagai produk masyarakat dan budaya tempat dia berasal dan berada. Fungsi kehakiman adalah memutus sengketa antara individu dengan individu, individu dengan masyarakat, bahkan individu atau masyarakat dengan negara; membentuk atau membuat policy atau kebijakan.

Keywords: judge; society; judicial power.

\section{Introduction}

The Indonesian state, which in fact is a constitutional state, then everything concerning the violation of the law or not obeying the existing legal rules will receive strict sanctions for the perpetrators. It is advisable for anyone who lives as a member of society who lives on this earth to be able to create social order properly, namely upholding the applicable law. The law must be enforced without selective logging in legal cases.

The law that is recorded in written regulations as well as the rule of law and in unwritten law is something abstract and generally accepted. Meanwhile, the law is concrete and specific when it has been applied/enforced in certain cases.

Laws are basically made to create order and peace in society. Therefore, the system of a law must run like a series of community organs must complement each other and have a high awareness of the applicable law. The paradigm that views law as a system has dominated the thinking of most legal circles, both theorists and practitioners since the birth of the modern state in the 17th century until now, namely the paradigm that considers law as an order. 
In Weber's view, law is an order that is coercive because the upholding of the legal order (which differs from other non-legal social norms and orders) is fully supported by the coercive power of the state. Weber distinguishes between various legal systems on the basis of substantive and formal rationality. Weber said that it has a substantive rationality when the substance of the law does consist of general rules in abstracto that are ready to be deduced to punish various concrete cases. On the other hand, law is said to have no substantive rationality if every case is resolved on the basis of political or ethical policies that are unique in its order. It may even be resolved emotionally which simply cannot refer to the general rules that are objectively present. On the other hand, law can be said to have formal (irrational) rationality if the law is only obtained through inspirations or through wangsit whispers which are said to be accepted by charismatic leaders so that its truth and worthiness cannot be objectively tested (Wignjosoebroto, 2008: 36-37).

Law is one of the fields whose existence is very essential to ensure the life of society and the state, especially as Indonesia is a state of law, which means that every act of state officials must be based on law, and every citizen must obey the law. With today's increasingly complex world developments, it is not uncommon for them to cause serious problems that need attention as early as possible. The problems that arise, either in the form of violations of existing norms in social life or rules that have the tendency to create a phenomenon that is contrary to moral and moral rules as well as legal rules. The violations that occur are the reality of human existence who cannot accept the rules as a whole. If such things are allowed to drag on and get less attention, it will cause unrest in society so that it can disturb public order (Iswanty, 2012: 390).

The enforcement of the rule of law is a human effort to achieve the order or order it needs. In terms of enforcement, the main thing is to synergize the three pillars, namely laws and regulations, law enforcement officers, and the legal culture of the community. Judges as part of the law enforcement apparatus (judicial power) have a very important role in the birth of a just rule of law and through various decisions judges are able to become a means of regulating public order. 
Courts through judges' decisions have the role of transforming ideas that come from abstract moral values into concrete events, so that the judge's decision visualizes abstract principles into concrete legal rules. In every case the incident will be seen, acknowledged or justified. The judge proves by means of evidence in order to obtain certainty that the incident qualifies, including in what or which legal relationship. The judge will look for provisions that can be applied to the legal event concerned. So, the Judge will apply the law to the event and evaluate it and in turn assign the law to the incident that occurs, of course he will give justice according to his judgment. The laws that are applied in society will have an impact on society. In the law enforcement process, the court decides on a case.

Humans are social creatures, creatures in groups. The human community deliberately creates an order in the form of social rules which has been continuously going on for centuries. This social order is institutionalized through a process of habituation (habitualization), that is, each action that is often repeated and eventually becomes a pattern. This development gradually crystallized into a habit (folkways).

There is a strong trend in that some of the behaviors are formulated in community laws. As a rule of law, it regulates what can and cannot be done, or what procedures must be followed, where the sanctions imposed by society for individuals who cannot conform are strict. The creation of this law is in line with the natural desire of humans to obtain or obtain justice in life together as members of society, so as to create order and order in a social order.

In addition to law as a tool to change society, law can also be left behind from social changes in society if it turns out that the law is unable to meet the needs of society at a certain time and place which can hinder development in other fields. The abandonment of the rule of law can also lead to disorganization, which is a condition in which the old rules have faded away, while the new rules as their substitute have not been developed or formed. This situation can then lead to anomaly, which is a chaotic situation, because there is no guideline for community members to measure their activities.

Thus, humans who live in society inevitably in the development stage of their life will always be confronted with an applicable rule or 
law. Judges are at the forefront of deciding and adjudicating a legal event. The thing that becomes a reference in the objective reality of society that comes from the creation of rules or sanctions that apply from the state or government is at the legal level. The law is strict and compelling when it aims to create order and peace in a society.

Law that exists in society is the law used to regulate cases of rationality, namely empirical, not speculative. If the law is enforced with justice, the law will be upheld in society. The law does not look at social classes, people's awareness in law that will determine the course of law enforcement in Indonesia. Once the role of the judge is important in facing the development of society, it will become the basis for fulfilling the rights of justice seekers, namely the community in enforcing the law in an integrated manner through the available court channels.

Based on the description above and on the premise that people's life activities are dynamic, they always develop rapidly, especially in the current era of globalization. Especially when society is entering a transitional period like in Indonesia today, and with the diversity of cultures and values that develop in it as well as globalization which results in various influences from other legal systems. Therefore, a law enforcer, including a judge, in its role to enforce the law in court by making fair legal breakthroughs. For this reason, the authors are interested in pouring the analysis and research into a paper entitled: "The Role of Judges in Facing Community Development". Hopefully it will be able to provide a systematic and holistic perspective on legal scientific treasures related to the implementation of law enforcement by judges in facing the dynamic development of society.

The research method is knowledge of systematic and logical steps in searching for data relating to a particular problem to be processed, analyzed, then drawn or concluded. The research model is qualitative with the type of research, namely the normative juridical research approach. Through the approach of statutory regulations, legal doctrines and legal theories. Data collection techniques in this research are documentation studies of various laws and regulations, legal doctrines and legal theories related to the role of judges in facing community development, for further analysis using data reduction, data presentation, and drawing conclusions. 


\section{Discussion}

\section{Arrangement of Judicial Powers}

The concept of judicial power in Indonesian law is closely related to the political dynamics of Indonesian history. Judicial power has been designed to support the political power of the rulers, both during the Old Order and New Order times. In the Reformation Era, this abuse of power was corrected by the amendment to the 1945 Constitution (UUD 1945) which attempted to position the judiciary and judges apart from executive power. However, there are those who do not realize that after the amendments to the 1945 Constitution, the independence of judges personally is actually eliminated (Irianto, 2017: 1).

The history of Indonesian justice, the portrait of the implementation of judicial duties has always been influenced by the prevailing politics of the era. Starting from the era of Dutch East Indies colonialism to the era of independence during the Reformation Era, politics has always influenced the Indonesian judicial system. According to Sudikno Mertokusumo, "the judicial system is influenced by the system of government, economy, and politics" and the discussion about Indonesian justice "cannot be separated from the development of the constitution or the constitution of the state in Indonesia." (Mertokusumo, 2011: 259).

Long before the establishment of the Republic of Indonesia, the official regulation of the judicial system had been in place since the era of Dutch East Indies colonialism. This arrangement was adjusted to the political interests of Dutch East Indies colonialism which was colonizing Indonesia. That is why the regulation of the scope of authority of judges, procedural law, and the division of types of court in a discriminatory manner was regulated in such a way by the Dutch East Indies colonial power so that it remained entrenched in the colony. During the Japanese occupation (1942-1945), according to Sudikno Mertokusumo, the judicial system in effect was only a simplification of the judicial system in effect during the Dutch East Indies era (Mertokusumo, 2011: 22).

The Indonesian judicial system after the proclamation of independence on 17 August 1945 was, to some extent, a continuation 
of the judicial system inherited from Dutch East Indies colonialism. However, this continuation was not one hundred percent the same as during colonialism because certain adjustments were made in line with the spirit of independence and the values held by the Indonesian people. The judiciary, for example, is no longer dominated by Dutch judges. Even so, the existence of the judicial system and court institutions in the course of Indonesian history has not been separated from political influence.

In the Soekarno era, under the Guided Democracy policy, the freedom and autonomy of judges was limited. Likewise during the Soeharto era, because through the policy of economic growth as commander-in-chief, the executive branch regained control of the judiciary. The two regimes confirmed the executive power over the judiciary through the issuance of various laws (UU). His reflection appears to be from the government side that has never lost as in Pompe's research when he fought against society for 40 years (Pompe, 2012). This happens because the government has always been a repeat player; the party who has all the resources to win the case, as Marc Galanter said (Galanter, 1974: 95).

During the New Order era, a two-roof system prevailed. Judges in the technical aspects of the judiciary are under the Supreme Court. However, in organizational, administrative, and financial matters, judges are under the government bureaucracy (Ministry of Justice). So strong was executive power that it was difficult to distinguish between judges serving the government or the political party in power. In practice, judges are more subject to executives who determine their welfare and careers. In fact, the executive can use his political power to gain the loyalty of judges. At that time also, judges were given the status of civil servants (PNS) whose monoloyalty was addressed to the government (Irianto, 2017: 5).

Meanwhile, in relation to its technical judicial functions, the Supreme Court's internal supervision of judges applies. Internal supervision is carried out by judges with a higher position over the judges who are below him. Although under the roof of the Supreme Court, the executive power is so strong that it can penetrate the judicial area. So, in this imbalanced power relation, the area of internal supervision of judges can be used to pressure judges to be 
loyal to the executive. The picture of the world of justice at that time was the potential abuse of power and the proliferation of nepotism and corruption in the judiciary.

The arrival of the reform era that ended the rule of the New Order had a very significant impact on judicial reform in Indonesia. Law No. 35 of 1999 (Law No. 35 of 1999) is a milestone for the one-stop policy. MA deals with all aspects, including administrative, financial, and organizational matters previously in the hands of the executive. The transfer is carried out in stages for general, religious, military and state administrative courts. The embodiment of the conversion of two roofs into one roof was carried out in 2001 through the third amendment to the 1945 Constitution, which is normally regulated in Article 24 paragraph (1) of the 1945 Constitution.

Indonesia is a rule of law that always prioritizes law as the basis for all activities of the state and society. Indonesia's commitment as a rule of law has always been and is only stated in writing in Article 1 paragraph (3) of the amended 1945 Constitution of the Republic of Indonesia. Wherever, a country wants its country to have law enforcers and laws that are fair, firmly not favoritism. One of the law enforcement is law enforcement in court to settle a proposed case.

During the examination at court proceedings, the judge who leads the proceedings of the trial must be active in asking questions and give the opportunity to the defendant represented by his legal adviser to ask the witnesses, as well as the public prosecutor. Thus, it is hoped that the material truth will be revealed, and the judge is responsible for everything he decides.

\section{The Role of Judges as Law Enforcers}

The most important component contained in the rule of law principle is the existence of "separation of powers" and "independence/independence of the judiciary" (judiciary body). The independence of the judiciary is a symbol of fair and impartial law enforcement. According to Soerjono Soekanto, the essence of the (good) law enforcement process is the harmonious application of values and rules which are then manifested in behavior. This pattern of behavior is not limited to members of the community, but also includes the "pattern setting group" which can be interpreted as a law 
enforcer in a narrow sense (Witanto and Kutawaringin, 2013: 3; Badriyah, 2016: 1).

The judge who is personified in an elected human figure called "qadi" is often also depicted as the Goddess Themis with her eyes closed as a symbol of neutrality and impartiality; will not look right or left or flirt with one of the litigants. In the teachings of classical legal philosophy, the judge must follow the "unconditional obligation" without having any intention of having bad thoughts. Therefore, according to Montesquie, judges only act as la bouche qui prononce les paroles des lois (limited to a funnel that sounds the words of the law) (Irianto, 2017: 9).

By seeing it in the organizational structure and mechanically, this makes the judge as a person who is free of values and free from interests, because he is released from everything that is human and completely avoids environmental influences. The problem is how it is possible for judges to work on analyzing cases only "purely" based on the prevailing legal norms.

A judge has at least some form of accountability in adjudicating a case, being responsible means the willingness and courage to carry out as well as possible everything that becomes his authority and duties. The responsibilities of judges are as follows:

1. The responsibility of the judge towards one God;

2. The responsibility of judges to the nation and state;

3. The judge's responsibility towards himself;

4. The responsibility of the judge towards the law;

5. The responsibility of the judge towards the parties;

6. Responsibilities of judges to society (Annisa, 2017: 161-163).

That is how heavy the responsibility of judges in examining and deciding cases places Judges in a noble position. Because of his position, the judge is confronted with several legal principles attached to his position, including:

1. A judge (court) may not reject a case submitted to him on the grounds that the law is unclear. This principle stipulates that a Judge who is presented with a case is obliged to examine it, and is not allowed to refuse on the grounds that the law is not 
clear, but the Judge must be able to prove the truth of the criminal event that occurred in the case presented to him, and he must be able to find the law;

2. What has been decided by the judge must be considered true (res judicata proveritate habetur). This provision indicates that the Judge in deciding a case submitted to him is the correct decision, because the Judge sees from the valid evidence presented to him, and is supported by his conviction of the perpetrator's guilt based on the available evidence.

3. The judge must judge, not make the law (judicis est jus dictare, non dare). This is to determine that a Judge whose main task is to examine and decide a case is based on valid evidence and his belief in the truth is based on such legal evidence, so that the decision can be accounted for and is considered fair. Judges are not allowed to issue decisions without being based on evidence and make decisions that must be obeyed by the parties in a case. Even so, in adjudicating a case the Judge determines the law concretely, so that the decision on collection rights can be considered as law (judge made law), but in the formation of the law, the Judge's decision is limited by law and bound by law;

4. There is no good judge in his own case (nemo judex idoneus in propria causa). This provision implies that the judge in examining a case must be a case that has nothing to do with himself and his family, meaning that the judge examining the case must not have an interest in the case because the parties in the case are still related by blood or brotherhood with the judge (Priyanto, 2010: 6).

Some of the principles mentioned above become the basis for carrying out the task of examining and deciding cases. The task of examining and deciding cases is not an easy task. The judge must be able to place himself in the objectivity of the cases that are presented to him. The judge must be careful in examining the case and can prove that the case submitted to him is really a case which is not the result of fabrication and is not colored by other interests, especially political interests. 


\section{Judges and Community Development}

Judicial power or in English is often referred to as 'the judiciary'. The main and first function of the branch of the judicial power is to decide disputes (resolving disputes) between individuals and individuals, individuals and communities, even individuals or society and the state. The second function is to form or make a policy or policy (KY, 2018: 62). In a legal system, likening the legal structure to a vehicle where the judge as the driver will determine the direction and decision of a legal event, and in the legal context this vehicle refers to the legal institution.

In the process of change that occurs in society, there is usually a force that is the pioneer of change or agent of change. We know various social groups as agents of change, for example the government, schools, political organizations, intellectuals, farmers and so on. What about the law, to what extent is the legal operation in changing society? This is an important question, considering that Indonesian society is experiencing development and changes in all fields. Development contains dynamic aspects even though many argue that the law maintains the status quo.

The reality of life provides many examples that there has been a very rapid and observable change. Change is seen as the fact that there is a distinction between the past and the present, and at the same time records the knowledge that what is now, whatever the difference from the past, is actually the result of the development of the facts that originally existed. Based on the Galilean Newtonian concept, nothing in the universe is eternal, change is a necessity based on the principle of cause and effect which is random. Longfellow said: "All muct change to something new ang something strange" (Suteki, 2015: 26).

Legal change (legal change) and social change (social change) are two things that have always been a concern and study of legal experts and other social scientists, how the relationship between law and social change. The first concern in the definition of the relationship between law and social change is the definition or problem of definition, what is meant by social change. In simple terms, social change can be interpreted as a restructuring of the basic patterns in which people in certain societal structures engage with one another in 
the fields of government, politics, law, economy, education, religion, family life and other activities.

According to Mochtar Kusumaatmadja, social changes that occur in a structured manner in the form of regular and systemized changes in society are a form of community development. Community development or social change is a matter of renewing ways of thinking and attitudes to life, without changing attitudes and ways of thinking, the introduction of new institutions in life will certainly not succeed (Kusumaatmadja, 2006: 10).

We can say that the role of law in development is an instrument to ensure that the social changes that occur will run regularly. Regular social change through legal procedures, whether in the form of statutory regulations or judicial decisions will be better than irregular change, especially through violent means, change or order (order) are the twin goals of society. which is undergoing change (Kusumatmadja, 2006: 20).

Learning from the history of the development of advanced societies in the world today, it can be seen that the social changes or development that they carry out generally go through a long journey which is carried out systematically through successive stages, namely the unification stage, the industrialization stage and the welfare state stage. In the first stage the serious problem is how to achieve political integration to create national unity and unity, in the second stage, the main task of the state is to develop the economy and political modernization and in the third stage the main task of the state is to protect the people from the negative side of industrialization, to improve mistakes in the previous stages by prioritizing the level of community welfare. National unity is a prerequisite for an industrialized society and industrialization is the path to a prosperous society (Rajagukguk, 1997: 1).

Developing countries, including Indonesia, in their efforts to catch up with other developed countries, generally try to put the attainment of the three stages of development together. Especially for Indonesia, if the three stages of achievement will be carried out simultaneously and simultaneously, then one thing that is one of the keys to determining success requires a legal culture that is able to accommodate the goals we are trying to achieve. 
In the context of societal or social change, law must be understood and developed as a single system in which there are various elements that are interconnected and inseparable from one another (Ashiddiqiew, 2006: 2). Renewal of attitudes, characteristics or values is necessary, what matters is which community values will be abandoned and replaced with new values that are deemed appropriate to community life, and which old values will still be preserved (Kusumaatmadja, 2006: 11).

Every case that is submitted to the court must continue to be tried, regardless after being tried and the judge declares that the case is not within the scope of his competence, the court must continue to adjudicate, regardless after being tried the judge declares that the case is not a legal event that must be tried or not in the scope of its competence, the court must declare it in the form of a decision not in the form of a case rejection before being tried.

The judge is a product of the society and culture where he comes from and is. Judges as individuals with various backgrounds and the reality of their experiences are important to learn. By understanding the existence of judges from several points of view, a comprehensive explanation of the various problems faced by judges can be obtained. Thus, it is also obtained an explanation of how the functions and roles of judges are carried out, the obstacles they face, as well as access and support in maximizing all their knowledge and abilities, so as to produce good quality decisions in fulfilling the sense of justice in society (Irianto, 2010: 2).

As a broader and living system, society consists of various subsystems, namely cultural, social, political and economic subsystems. In Talcott Parsons' Cybernetics Theory, it is stated that the primary function of the social subsystem in a wider society is to integrate various interests that are diverse, plural, and even opposing each other so that they often form friction in social interactions. In a broad social system, law falls within the area of the social sub-system so that the main function of law is also as an integrating mechanism. In law enforcement practices, courts in Indonesia carry out an integration function represented by judges, so that judges have the responsibility to bring justice to the people and truth (seacrhing for 
the truth) in order to create social integration, not the other way around creating social disintegration (Suteki, 2015: 80-81).

Judges are believed to be figures capable of integrating various kinds of interests, differences and frictions through conversion equipped with inputs in the form of adaptive functions so as to maintain the integration pattern. After carrying out the conversion process in court institutions, the decisions made by judges are expected to fulfill the elements of efficiency, legitimacy and justice.

In the Common Law system, judges can create laws, new laws, known as the judge made law principle, so that judges are truly independent, not shackled by mere statutory regulations (la bouche de la loi). In the context of law enforcement in Indonesia, judges in examining and adjudicating a case, although in a case faced by a judge there is no legal regulation or legal regulation but it is not clear, the judge cannot refuse to try a case. This is expressly stated in Article 10 paragraph (1) of Law no. 48 of 2009 concerning Judicial Power which states that: "Courts are prohibited from refusing to examine, hear and decide a case filed on the pretext that the law does not exist or is unclear, but is obliged to examine and judge it". In the event that a judge has to decide a case where there is no legal rule, the judge here must try to find the law, both written law and unwritten law.

The judge has so much authority. This is because judges who are the main actors in the judicial power have the responsibility to hear, examine and decide cases. With his ruling, the judge can resolve disputes, eliminating ownership. In fact, it can even be done by a judge. So much is the power of a judge that any problem that comes to him, even though it is unclear, incomplete, or even without rules, is obliged to decide the case by trying to dig or make legal findings (rechtsvinding) (Wijayanto, 2018: 5).

The role of the judge is to understand the purpose of law in society, to explore justice and values that live in society, because the law in society is like a living organism. Laws in society are always factual and are in constant change. The changes can be minor and gradual and difficult to observe, but they can also be drastic. The relationship between law and reality is so fluid, it causes the law to always change. In many ways, changes in law are the result of changing social realities. 
However, there are times when the law wobbles in keeping with changes in society, causing a "gap" between society and the law. This means that the law may not be in a watertight space, but rather tries to adapt to the development of society. The history of law is a history of adaptation to the changing needs of life. In that case, the judge has the main role and responsibility to make changes to the law. Judges can make changes by interpreting the law. In that case, the role of the judge becomes significant in bridging the gap between outdated laws and developments in society. A judge cannot say that matters of legal change are the sole responsibility of the legislature. Courts must take on the role of changing the law jointly with the legislature.

Justice seekers certainly really want that cases submitted to court can be decided by judges who are professional and have high moral integrity so that they can create decisions that not only contain legal justice but also include moral justice (moral justice) and social justice (social justice).

Seeing the law, society, courts and judges cannot stand alone. The relationship is dynamic, because changes that occur in one aspect affect other aspects. The problem is, the change in law that follows changes in society is like a double-edged sword. When a conscious change of law is made to capture the needs of society, the gap between the two can be bridged.

A judge's decision that has been pronounced in a trial that is open to the public will not only have an influence on the parties in litigation, but will also have implications for the wider community, so that the decision must not only reflect public justice. A good decision is a decision that can reflect a change in the dynamics of people's life for a better direction, or at least it can be a deterrent to community behavior that violates the law, so that decisions can be an effective medium in creating legal order in society, on a scale. small decisions are media for resolving cases being tried, but in a broad sense the considerations of the decision will be polarized into a generally accepted rule in society because it contains good values for people's lives.

The responsibility of judges to the community is not in the sense of fulfilling every wish of the community, or in other words simply following the wishes of the mainstream in society, because the form of 
a judge's accountability to the community is not aimed at a particular group that has an interest in the case being examined. At present the community often becomes a tool for stakeholders to influence judges' decisions, so that judges become shackled by the opinions and desires of the public at large, even though what a group of people voices is not always true because the dimensions of conveying information about case material to the public are also not always correct, but sometimes it has been engineered into contradictory issues with the real facts.

In reality, judges are strongly influenced by diverse identities, at least based on life history, ethnicity and cultural traditions, class, religious beliefs, political views, class, gender, and even scientific ideology. Thus, the "juridical-normative" decision actually also contains a "sociological-cultural" claim in line with the diversity and overlapping identities of a judge. However, it is sometimes not realized by the judges themselves and the wider community. The awareness that judges are human encourages us to see judges in their full human quality.

Thus, it is important to see that judges are also a product of society. A society with shifting values and permissiveness to corruption may also produce judges who are insensitive to corruption. For example, judges who interpret acts of corruption are limited to the text of the law, there are elements of self-enriching and detrimental to the state from government employees and corporations that will cause acts of corruption that are so diverse and in scope that they cannot be categorized as corruption. Judges find it difficult to produce new legal findings that come out of formal procedural justice and think about substantial justice.

The judge interpreted his existence as part of the community, even as a product of society. This has an impact on the way the judge responds to the various cases he has to decide. Another thing that is no less important is to study the judge's meaning of himself as part of the legal structure in law enforcement institutions (Rahardjo, 2003: 224; Makbul, 2016: 19).

The use of law as a tool of change in society requires legal experts to have more and broader knowledge than legal knowledge in the sense that we are familiar with it so far, a legal expert in this context must be able to understand the interaction between the law and other 
factors develop in society, be it social, economic, political, cultural and other factors.

These difficulties often lead to lags and even failure of the role of law in accommodating development interests or changes in society. Changes in the field of law will have an impact on other areas of life, and vice versa. The legal function, on the one hand, can be used for means and means of changing society towards a better order and on the other hand, the law can also be used for means and tools to maintain the existing social order.

Legislation as a tool of change in society, besides having the advantages as above also has weaknesses, among others, it is often found that laws and regulations are not able to adapt to the rapidly changing development of society, laws and regulations are also not able to comprehensively accommodate the interests that exist in society.

The plurality of society in Indonesia (part of Asia) should be the basis for the direction of law enforcement. Law and society have a very strong relationship, even Tamanaha said that law has a peculiar form of social life. Brian Z Tamanaha said that law and society have a frame called The Law-Society Framework which has certain relationship characteristics. Understanding law and the way of law in Indonesia can no longer be approached through three classical approaches such as a philosophical approach, a juridical approach and a sociological approach. However, another approach is needed, as Menski offers a fourth approach known as the legal pluralism approach. The legal pluralism approach relies on the link between the state (positive law), social aspects (socio-legal) and natural law (moral/ethical/religious). The method of law that only relies on positive law with rule and logic and its rule bound will only lead to a deadlock in the search for substantive justice.

The legal pluralism approach must be mastered by law enforcers in making legal breakthroughs through the non enforcement of law, because this approach is no longer imprisoned by legal formalism but has jumped towards the consideration of living law and natural law. The method of law in Indonesia is not appropriate if a juridical (positivistic) approach is used, such as the country of origin of Indonesian law (continental Europe), without considering 
moral/religious aspects and socio-legal considerations. The liberal individualistic character of modern law in Indonesia must be balanced with the character of wisdom and compassion, unity and a sense of justice in society that is reflected in the living law, so that the law is able to present complete justice which is the goal of progressive law enforcement.

As a progressive judge, in carrying out his duties and authority, it is based on two components which include rules and behavior. The law is for humans, not the other way around. Starting from this basic assumption, the judge's presence is not for himself, but for something broader. So great is the responsibility of a judge, not only to the parties involved in a case, but also to the community and the highest responsibility of a judge is towards God. Because basically the judge is the representative of God in the world and as a form of judge's responsibility, so in every verdict issued by the judge in the head of his decision there is always the sentence "For Justice Based on the One Godhead".

The creativity of judges in making legal breakthroughs is part of the spirit of liberation against the culture of law enforcement (administration of justice), which has been in power and is considered to be hindering legal efforts to resolve problems. Encourage judges so that in the process of law enforcement, judges must dare to free themselves from the use of standard patterns (normative-positivistic) that emphasize mere normative justice (normative jusctice), because in fact the search for justice cannot only be seen from the normative aspect, but also from the normative aspect. sociology, especially when it comes to aspects of social justice and the constitutionality of a law.

Therefore, the role of law as a tool for change in society will always involve other legal components, one of which is the judge (legal structure) to work as a system that is inseparable and complementary and complementary, so that the void in statutory regulations can always be filled by law. which in fact lives and is obeyed in the community and in the life of society there is never a legal vacuum.

\section{Factors Affecting Judges in Actualizing Legal Justice in Society}


Judges' verdicts in the form of words (language) which actually contain the juridical thinking activities of the maker (judge). He will constrict, systematize and conclude. This activity appears to be applied in the fulfillment of a legal rule that will be applied to a collection of events presented by the parties, or in a mindset of consideration (motivation), so that between legal considerations and decisions (amar) has a logical sequence. But no less important, conceptually the decision must provide individual justice in each case (case).

For every individual the most important thing is that the decision fits and fulfills a sense of justice. Unfortunately because there are two conflicting parties in the case, there are different perceptions in dealing with a decision. The losing party tends to say, it is not fair, there is collusion and various other tones that discredit the Court.

Legal wills in the reality of everyday life are carried out through humans. Based on this vision, humans who carry out law enforcement really occupy an important and decisive position. What the law says and promises, will eventually come true through the hands of these people. Therefore, judges as law enforcement subjects are able to influence the upholding of a law in social life.

Psychologically, everyone wants to live happily and avoid misery, so that when declared defeated, he will look for efforts to improve his position. Likewise, judges have psychological values in examining each case until they finally issue a decision. The law provides provisions for legal remedies if he is not satisfied with the judge's decision. However, after reaching the highest level of justice even when the case is about to be executed, they do not voluntarily carry out the sound of the verdict. This is of course a burden on the court.

Judges in actualizing the idea of justice need a conducive situation, both from external and internal factors from within a judge.

a. Guarantee of freedom of trial/judge (Independence of Judiciary)

Judicial freedom has become a necessity for the establishment of a rule of law (rechstaat). The judge will be independent and impartial in deciding disputes, and in such a conducive situation, the judge will be free to transform ideas in the considerations of the decision. In Indonesia, guarantees for independence of 
judiciary have been put in place as a foundation in Articles 24 and 25 of the 1945 Constitution of the Republic of Indonesia which are emphasized in the intended explanation: "Judicial power is independent power, meaning that regardless of the influence of government power, in connection with this there must be a guarantee in the Law regarding the position of the Judges ".

This is emphasized again in the explanation of Article 1 of Law No. 14 of 1970 jo. Law No. 4 of 2004 concerning the Principles of Judicial Power which states: "This independent judicial power contains the meaning in it that judicial power is free from interference by other state powers, and freedom from coercion, directives or recommendations that come from extra-judicial parties except in the case of -things permitted by law".

Independent judicial power serves two purposes. First, to carry out the functions and authorities of the judiciary honestly and fairly, secondly, so that the judicial power is able to play a role in supervising all actions of the authorities (Soekanto, 1993: 5). While the consequences of an independent judicial power are:

a. The rule of law. Every dispute resolution must be in accordance with the process prescribed by law based on the principles of equal treatment before the law and equal protection before the law;

b. Justice as a pressure valve. The judiciary is given the authority as a pressure valve for any violation of the law committed by anyone and any party without exception and the violation includes all forms of unconstitutional, public order and propriety acts;

c. Justice as the last resort in upholding truth and justice places the judiciary as the last place;

d. Judiciary as the implementer of law enforcement;

e. The judiciary is justified in acting "fundamentally undemocratic": it does not require access from anyone, does not require negotiation from any party and does not require "compromise" from the litigating party;

There is general agreement in the court community in the world that judicial institutions are expected to do the following: 
1. Courts provide individual justice in individual cases;

2. Courts operate in a transparent manner;

3. The court provides an impartial forum in resolving legal disputes;

4. Courts protect citizens from the arbitrary use of government power;

5. Courts protect the weak;

6. Courts maintain and maintain formal records of decisions and legal status.

Based on these provisions, actually the regulation on the independence of the judicial power looks solid.

b. Quality of Judge Professionalism

Each judge is required to carry out his duties in a professional manner, namely the ability and skills of the judge to carry out the efficiency and effectiveness of decisions. Both in terms of the application of the law, as well as the ability to consider decisions based on the values of justice that grow and develop in society, as well as the ability to predict reactions and social impacts on decisions that have been passed.

This professionalism is one side of the "profession" currency, besides the side of professional ethics. So, every profession has two aspects, namely professionalism as a technical expertise and professional ethics as the basis of morality. Professionalism has an important role, especially when judges carry out juridical responsibilities and obligations related to their positions. Basic Law on Judicial Power No. 14 of 1974 jo. Law No. 4 of 2004 obliges Judges (Article 14 paragraph (1)): "... may not refuse to examine and try a case filed on the pretext that the law is not clear or unclear, but is obliged to examine and judge it".

In an effort to realize the professionalism of Judges, Judges should have a deep mastery of knowledge and broad insight, which is reflected in the weight and for decisions that are passed with the ability to know, understand and live the applicable law and have the courage to make decisions based on law and justice.

c. Living with Professional Ethics of Judges 
Judge professional ethics are the principles of morality that underlie the profession of Judges. Meaning as a guide in behaving and acting while carrying out and carrying out the position of a judge, both inside and outside the official.

The Indonesian Judge Association (IKAHI) has formulated a code of honor for Indonesian Judges in the form of Panca Dharma Hakim, which is a form of supervision of its members. These Panca Dharma Hakim values are abstract in nature, consisting of: Kartika: devotion to God Almighty; Chakra: be fair; Candra: wise; Tirta: honest; Sari: Virtuous.

\section{Conclusion}

Based on the above discussion regarding the role of judges in facing the development of society, the conclusions are as follows:

1. Judges are part of the important structure of the judicial power branch in Indonesia. Judicial power is an independent power to administer justice in order to uphold law and justice. Judges are state judicial officials who are empowered by law to judge. Judges have an important role as law enforcement officers in the law enforcement process in Indonesia, judges in examining and deciding cases must pay attention to the objectives of the law itself which include legal certainty, justice and legal benefits. The role of judges is so big, has consequences for the very heavy responsibility of the judge, where the judge has responsibility to one God, the nation and the state, to himself, to the law, to the parties and to society.

Judges and society are elements that cannot be separated from a legal system. The judge is a product of the society and culture where he comes from and is. The main and first function of the branch of the judicial power is to decide disputes (resolving disputes) between individuals and individuals, individuals and communities, even individuals or society and the state. The second function is to form or make a policy or policy. Community development is a necessity for social change. Legal change (legal change) and social change (social change) are two things that have always been a concern and study of 
legal experts and other social scientists, how the relationship between law and social change. Every case that is submitted to the court must continue to be tried, regardless after being tried the judge later states that the case is not within the scope of his competence, the court must continue to judge by exploring the values that live and develop in society. In the condition of society that continues to move faster than the law itself and the condition of a plural society in Indonesia, judges in deciding a case must go through various approaches including juridical, philosophical, sociological and legal pluralism approaches as a way of realizing the creativity of judges to make legal breakthroughs. who is able to answer problems in community development. [w]

\section{Reference}

Annisa, Nur Fitria. 2017. "Peranan Hakim Sebagai Penegak Hukum Berdasarkan Undang-Undang Nomor 48 Tahun 2009 Tentang Kekuasaan Kehakiman”, Jurnal Lex et Societatis V(3).

Ashiddiqie, Jimly. 2006. "Pembangunan Hukum d an Penegakan Hukum d i Indonesia." disampaikan pada seminar "menyoal Moral Penegak Hukum" Lustru XI Fakultas Hukum Universitas Gadjah Mada Badriyah, Siti Malikhatun. 2016. Sistem Penemuan Hukum Dalam Masyarakat Prismatik. Jakarta: Sinar Grafika.

Darmoko Yuti Witanto dan Arya Putra Negara Kutawaringin. 2013. Diskresi Hakim Sebuah Instrumen Menegakkan Keadilan Substantif Dalam Perkara-Perkara Pidana. Bandung: Alfabeta. Galanter, Marc. 1974. "Why the Haves Come Out Ahead: Speculations on the Limits of Legal Change", Law and Society Review.

Iriantoro, Catur. "Peranan Hakim danlam Menerapkan Hukum dan Mentransformasikan Ide Keadilan" http://www.pnmedankota.go.id/v3/index.php?option=com_c ontent\&view=article\&id=159:peranan- 
hakim\&catid=101: kumpulan-artikel\&Itemid=101, diakses pada 8 Januari 2020

Iswanty, Muji. 2012. "Pertanggungjawaban Medis Terhadap Terjadinya Abortus Provokatus Criminalis (Tinjauan Hukum Kesehatan dan Psikologi Hukum)", FH Universitas Hasanuddin, 1 (3).

Kusumaatmadja, Mochtar. 2006. Konsep - Konsep Hukum dalam Pembangunan. Bandung: Alumni.

Makbul, Agung. 2017. Tim Bantuan Hukum Polisi RI dalam rangka pembebasan anngota Garuda Bhayangkara FPU 8 di Daffur Utara, Sudan. Jakarta: Ibi Trans Media.

Makbul, Agung. 2016. Penegakan Undang-Undang Nomor 22 Tahun 2009 Tentang Lalu Lintas dan Angkutan Jalan oleh POLRI dalam Rangka Meningkatkan Budaya Hukum Disiplin Berlalu Lintas. Jakarta: Swastika Anugraha Mahardika.

Menski, Werner. 2006. Comparative Law in A Global Context: The Legal System of Asia and Africa. Cambridge: Cambridge University Press.

Mertokusumo, Sudikno. 2011. Sejarah Peradilan dan PerundangUndangannya di Indonesia Sejak 1942 dan Apakah Kemanfaatnya Bagi Kita Bangsa Indonesia. Yogyakarta: Universitas Atma Jaya Yogyakarta.

Moleong, Lexy J. Metodologi Penelitian Kualitatif. Bandung: Remaja Rosdakarya Offset.

Murphy, Walter F. 2005. et., al, Courts, Judges \& Politics, An Introduction to the Judicial Process, Sixth Edition. Boston: McGraw Hill.

Pompe, Sebastian. 2012. Runtuhnya Institusi Mahkamah Agung. Jakarta: Lembaga Kajian dan Advokasi untuk Indpendensi Peradilan.

Priyanto, Anang. Citra Hakim dan Penegakan Hukum dalam Sistem Peradilan Pidana Di Indonesia. Yogyakarta: FISIP UNY

Prodjodikoro, Wirjono. 2003. Asas-asas Hukum Pidana di Indonesia. Bandung: Refika Aditama.

Rahardjo, Satjipto. 2003. Sisi Lain dari Hukum. Jakarta: Kompas. 
Rahardjo, Satjipto. 2009. Pendidikan Hukum sebagai Pendidikan Manusia. Yogyakarta. Genta Publishing.

Rahardjo, Satjipto. 2004. "Menuju Produk Hukum Pregresif", Makalah Diskusi Terbatas pada Fakultas Hukum UNDIP.

Rajagukguk, Erman. 1997. "Peranan Hukum dalam Pembangunan pada Era Globalisasi: Implikasinya bagi Pendidikan Hukum di Indonesia” Pidato Pengukuhan Guru Besar dalam Bidang Hukum pada Fakultas Hukum Universitas Indonesia.

Soekanto, Soerjono. 1993. Faktor-Faktor yang Mempengaruhi Penegakan Hukum. Jakarta: RajaGrafindo Persada.

Sulistyowati Irianto, dkk., 2017. Problematika Hakim Dalam Ranah Hukum, Pengadilan, dan Masyarakat di Indonesia: Studi Sosio-Legal. Jakarta: Pusat Analisis dan Layanan Informasi Sekretariat Jenderal Komisi Yudisial RI.

Suryadi. 2010. "Fungsi Hukum sebagai Alat dan Cermin Perubahan Masyarakat", Journal of Rural and Development I (2).

Suteki. 2015. Masa Depan Hukum Progresif. Yogyakarta: Thafa Media.

Thohari, Ahsin. 2004. Komisi Yudisial dan Reformasi Peradilan. Jakarta: ELSAM.

Undang-Undang Dasar Negara Republik Indonesia 1945.

Undang-Undang No. 48 Tahun 2009 tentang Kekuasaan Kehakiman.

Wijayanto, Danang. 2018. Meluruskan Arah Manajemen Kekuasaan Kehakiman. Jakarta: Sekretariat Jenderal Komisi Yudisial RI.

Wignjosoebroto, Soetandyo. 2008. Hukum dalam Masyarakat. Malang: Bayumedia Publishing.

Zuhri, Muhammad Fakhruddin. "Forgiveness of Judges: Local Wisdom in the Concept of National Criminal Law." Walisongo Law Review (Walrev) 1.1 (2019). 
Maulana Hasanudin, The Role of Judges ...

WALISONGO LAW REVIEW (WALREV) Vol 02 No 2 Okt 2020 || 220 